\title{
Synthesis and use of nitrocyclopropane derivatives
}

\author{
Roberto Ballini,* Alessandro Palmieri, and Dennis Fiorini \\ Dipartimento di Scienze Chimiche, Università di Camerino, Via S. Agostino 1, 62032 Camerino, \\ Italy \\ E-mail: roberto.ballini@unicam.it
}

This review is dedicated to Prof. Atta-ur-Rahman on the occasion of his $65^{\text {th }}$ birthday

\begin{abstract}
Nitrocyclopropanes are strained-ring nitro compounds of special attraction in the field of energetic materials because of the increased performance expected from the additional energy release upon opening the strained ring system during decomposition. Moreover, the nitrocyclopropane moiety is the key structure of important natural products or the key building block for other important targets. Thus, the aim of this micro-report is focused on the main approaches for the synthesis of nitrocyclopropane derivatives and their chemistry.
\end{abstract}

Keywords: Nitroalkanes, conjugate addition, nitrocyclopropanation, energetic materials, strained-ring nitro compounds

\section{Contents}

1. Introduction

2. Nitrocyclopropanation by Michael addition of nitromethane to $\alpha$-bromo- $\alpha, \beta$-unsaturated ketones

3. Nitrocyclopropanation from nitrodiazomethanes

3.1. Synthesis of cyclopropane $\alpha$-amino acids and amines

4. Intramolecular cyclopropanation of $\gamma$-nitro alcohols

4.1. Intramolecular Mitsunobu displacement

4.2. Synthesis of 3-(trans-2'-nitrocyclopropyl)alanine

5. Cyclopropanation of tert-butyl 2,3-dibromopropanoate

6. Cyclopropanation of conjugate nitroalkenes

7. Cyclopropanation by Michael addition of bromonitromethane to electron-poor alkenes

8. Conclusions 


\section{Introduction}

Aliphatic nitro compounds are valuable intermediates and the chemical literature continuously reports their utilization for the synthesis of a variety of target molecules. ${ }^{1}$ The vast preparative potential of aliphatic nitro compounds and the efforts to develop efficient syntheses and utilization of functionalized aliphatic nitro derivatives have continued with increasing success. ${ }^{2-6}$

Cyclic nitro derivatives are of great interest due to their particular reactivity and synthetic applications. ${ }^{7}$ In this context, strained-ring nitro compounds are of special attraction in the field of energetic materials and nitrocyclopropanes are the simplest members of this class of compounds. These energetic materials play an important role in aeronautics, the weapons industry and other high-tech. fields at present. ${ }^{8}$ The development of new energetic materials and improvement of existing energetic materials have became the topic of interest for experimentalists and theoreticians. Strained-ring nitro compounds are at the forefront of the search for more and less sensitive energetic materials. ${ }^{9}$ In fact, nitrated small ring heterocycles and carbocycles are interesting as energetic materials because of the increased performance expected from the additional energy ${ }^{10}$ release upon opening the strained ring system during decomposition. ${ }^{11}$ Moreover, the nitrocyclopropane moiety is the key structure of important natural products such as hormaomycin 1 (Fig. 1), a peptide lactone with important biological activities, ${ }^{12}$ or the key building block for other important structures.

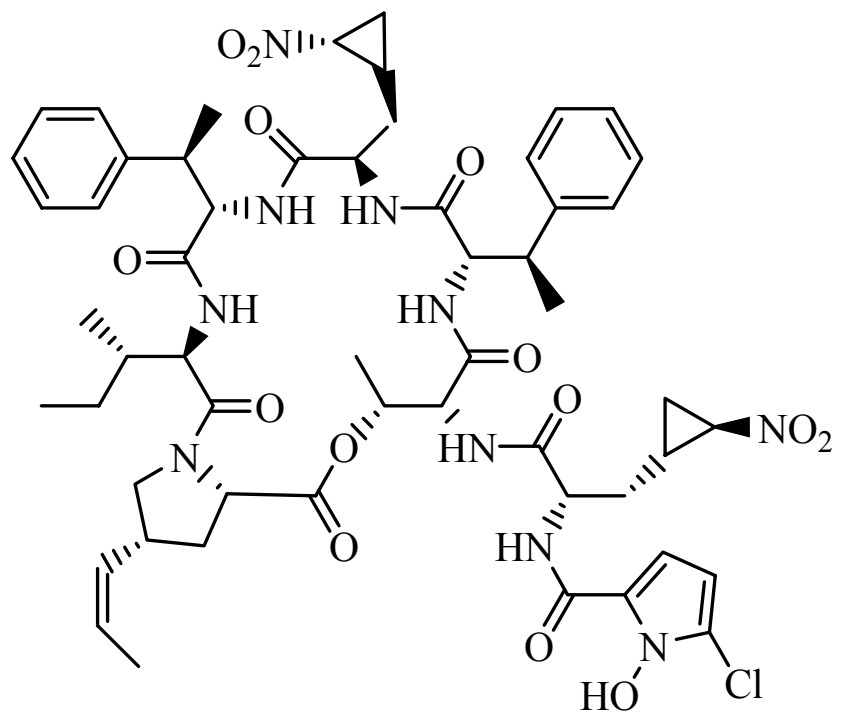

Figure 1. Hormaomycin

Thus, the aim of this micro-report is focused on the main approaches for the synthesis of nitro cyclopropane derivatives and their chemistry. 


\section{Nitrocyclopropanation by Michael addition of nitromethane to $\alpha$-bromo- $\alpha, \beta$-unsaturated ketones}

In the course of some investigations on the Michael addition of nitroalkanes to 3-oxo-1,4,6-triene steroids Kocór and Kroszczński carried out ${ }^{13}$ the addition of nitromethane to 2-bromo-3-oxo1,4,6-trienes $\mathbf{2}$ in order to obtain the corresponding 2-bromo-1 $\alpha$-nitromethyl steroids $\mathbf{4}$, suitable for further transformations. The addition reaction took place, but it was followed by a very fast dehydrobromination, proceeding in a rather unexpected fashion i.e. giving rise to the formation of $1 \alpha, 2 \alpha$-(nitromethylene)-3-oxo-4,6-dienes 5 as the only isolable products (Scheme 1).

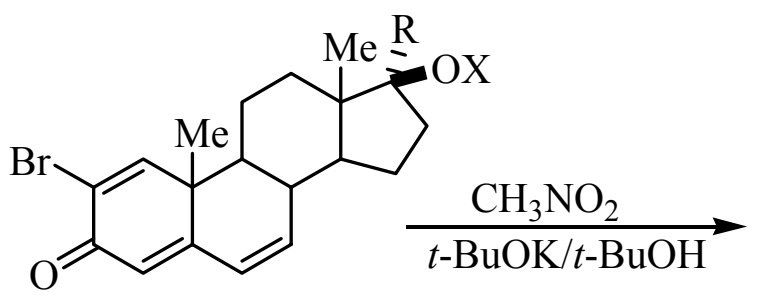

$\mathbf{2 a , b}$

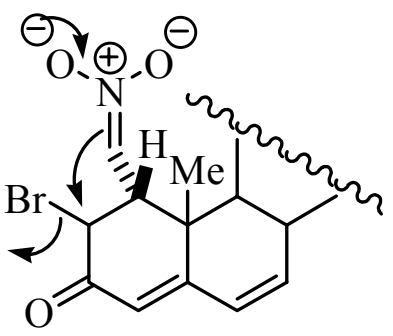

3a,b

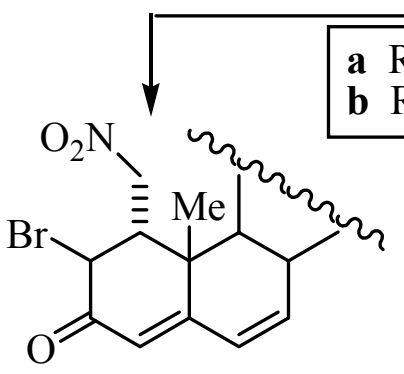

$4 \mathbf{a}, \mathbf{b}$

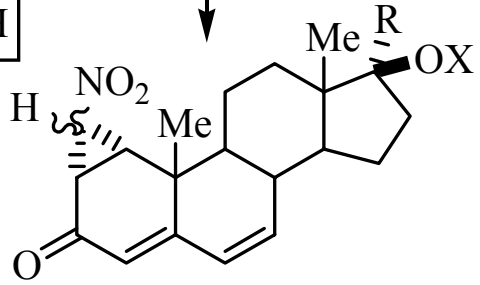

$\mathbf{5 a , b}$

\section{Scheme 1}

The compounds 5 were obtained in $25-27 \%$ yields, after ten days. However, in spite of moderate yields, the method seems to have general application for preparation of nitrocyclopropanes, and particularly for the synthesis of cyclopropane rings condensed with carbocyclic systems e.g. steroids. The authors assumed that the first obvious step of this reaction is the Michael addition to the $\mathrm{C}-1 / \mathrm{C}-2$ double bond from the less hindered $\alpha$-side. The addition of nitromethane in strongly alkaline medium results in the formation of the anion $\mathbf{3}$ of the aci-form of nitromethyl substituent. The reorganisation of electrons with simultaneous bromide ion elimination leads to the formation of cyclopropane ring. The described cyclopropanation reaction resembles slightly the formation of nitrocyclopranes reported by Kohler $^{14}$ and Perekalin; ${ }^{15}$ however, in their case the reaction sequences were different, e.g. Perekalin brominated the 
preformed $\gamma$-nitrocarbonyl compounds to $\alpha$-bromo- $\gamma$-nitro ketones, which were subjected to dehydrobromination as shown in the Scheme 2.<smiles>[R]C(=O)CCC([R])[N+](=O)[O-]</smiles>

\section{Scheme 2}

As development of the Kocór and Kroszczński procedure, later Arai and coll. ${ }^{16}$ reported an asymmetric cyclopropanation reaction using quaternary ammonium salts as the phase-transfer catalyst (PTC). The authors examined the reaction of nitromethane with $\alpha$-bromocyclopentenone 6 that seems to act as both as Michael acceptor and carbon electrophile in the presence of reactive nucleophiles under PTC conditions (Scheme 3).
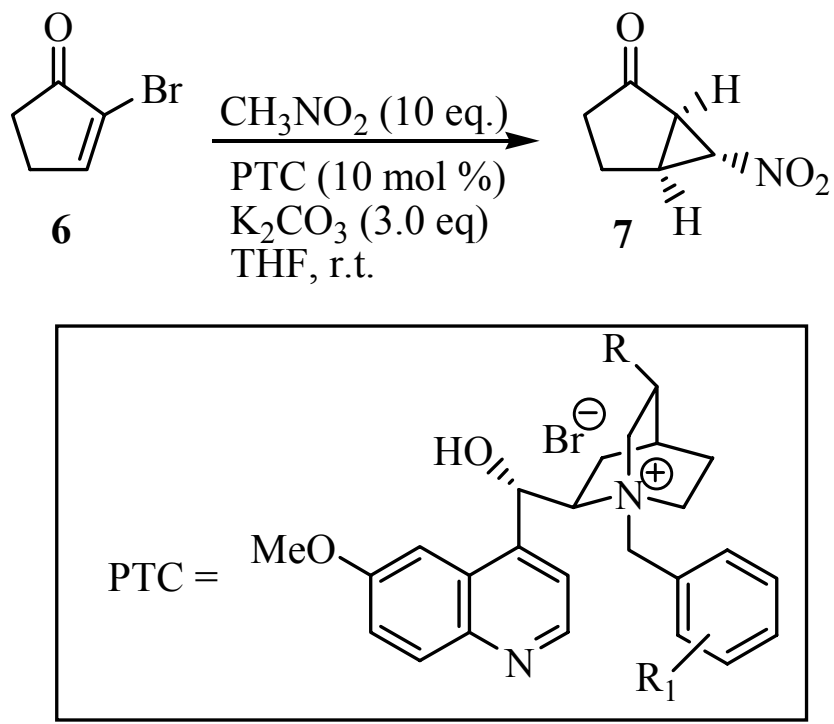

\section{Scheme 3}


The reaction proceeds with a stoichiometric amount of $\mathrm{K}_{2} \mathrm{CO}_{3}$ and $10 \mathrm{~mol} \%$ of PTC derived from quinidine to afford the desired product 7 . Although the chemical yields were low (Table 1), a PTC having an electron donating group was found to be effective (entries 3 and 4).

Table 1. Asymmetric cyclopropanation to 7

\begin{tabular}{|cccccc|}
\hline Entry & $\mathrm{R}$ & $\mathrm{R}_{1}$ & Time (h) $\begin{array}{c}\text { Yield } \\
(\%) \text { of } 7\end{array}$ & ee (\%) \\
\hline 1 & vinyl & $\mathrm{H}_{5}$ & 21 & 25 & 6 \\
2 & vinyl & $4-\mathrm{OMe}$ & 13 & 29 & 4 \\
3 & vinyl & $\mathrm{F}_{5}$ & 17 & 19 & 59 \\
4 & ethyl & $\mathrm{F}_{5}$ & 130 & 14 & 76 \\
5 & ethyl & $\mathrm{F}_{5}$ & 11 & $34^{\mathrm{b}}$ & 64 \\
6 & ethyl & $\mathrm{F}_{5}$ & 22 & $50^{\mathrm{b}}$ & $62^{\mathrm{c}, \mathrm{d}}$ \\
\hline
\end{tabular}

${ }^{a}$ Enantiomeric excess (by HPLC). ${ }^{\mathrm{b}}$ The reaction was carried out in the presence of $1 \mathrm{~mol} \%$ of $(n$ Hex $)_{4} \mathrm{NBr} .{ }^{c}$ Three equivalents of $\mathrm{Rb}_{2} \mathrm{CO}_{3}$ was used. ${ }^{\mathrm{d}}[\alpha]_{\mathrm{D}}+9.4\left(c, 0.75, \mathrm{CHCl}_{3}\right)$.

In order to increase the chemical yield, it was attempted to use achiral co-PTC to accelerate the reaction and avoid the decomposition of $\mathbf{6}$ under basic media. Although the racemic products could be obtained when the cyclopropanation promoted by achiral PTC is fast, the cation exchange between chiral and achiral ammonium salts would be expected as an effective process to afford the desired products as an optically active form in such a reaction system. Surprisingly, the addition of a catalytic amount $(1 \mathrm{~mol} \%)$ of tetrahexylammonium bromide (THBA) as an achiral co-PTC with chiral PTC (10 mol \%) was found to be quite effective to give the desired product 7 (entry 5) and also the reaction time is remarkably shorter. Moreover, the chemical yield was successfully increased to $50 \%$ (62\% ee) by use of $\mathrm{Rb}_{2} \mathrm{CO}_{3}$ instead of $\mathrm{K}_{2} \mathrm{CO}_{3}$ (entry 6). The relative configuration of 7 was determined by ${ }^{1} \mathrm{H}$ NMR through comparison to the literature data. ${ }^{17}$ The absolute configuration of 7 was determined by its denitration to the corresponding methylene cyclopropane by treatment with $n$ - $\mathrm{BuSnH}^{18}$ and the comparison of the optical rotation with the literature data. ${ }^{19}$

\section{Nitrocyclopropanation from nitrodiazomethanes}

Nitrodiazo compounds are ideal precursors to nitrocarbenes and are potentially accessible via the introduction of a diazo group into a nitro compound or via the introduction of a nitro group into a diazo compound.

Some years ago, it has been found ${ }^{20}$ that the addition of a solution of dinitrogen pentoxide, in halogenated solvent, to the diazo compound $\mathbf{8}$ gives, at low temperature, the nitrodiazo compounds 9 (Scheme 4). 


\begin{tabular}{|l}
$\mathrm{Ra-g}$ \\
$\mathrm{R}=\mathrm{CN}(\mathbf{a}), \mathrm{CO}_{2} \mathrm{Et}(\mathbf{b}), \mathrm{CO}_{2} \mathrm{Bu}^{t}(\mathbf{c})$, \\
$\mathrm{COPh}(\mathbf{d}), \mathrm{TolSO}_{2}(\mathbf{e}), \mathrm{CF}_{3}(\mathbf{f}), \mathrm{H}(\mathbf{g})$.
\end{tabular}

\section{Scheme 4}

The diazo compounds 9 undergo cyclopropanations with alkenes in the presence of a catalytic (0.5-3 mol \%) amount of rhodium(II) acetate (Scheme 5).

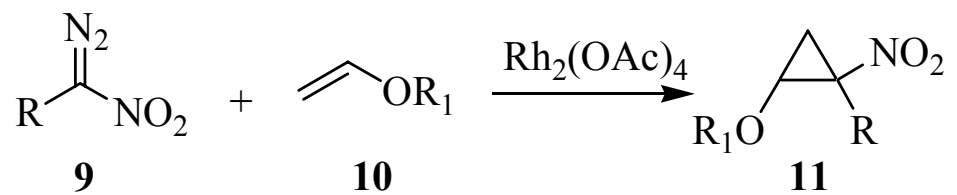

\section{Scheme 5}

The results from the cyclopropanation of various alkenes are presented in Table 2. Electron poor alkenes such as vinylidene chloride and ethyl acrylate do not yield cyclopropanes.

Table 2. Yield (\%)nitrocyclopropanes 11 prepared

\begin{tabular}{|ccccccc|}
\hline Alkene 10 & 9a & 9b & 9c & 9d & 9e & 9g \\
\hline styrene & 55 & 75 & 83 & 75 & 73 & 54 \\
isobutene & 50 & 50 & 75 & 80 & 58 & 50 \\
1-hexene & 55 & 35 & & & & 50 \\
cis-2-butene & 40 & 65 & 59 & 45 & 53 & 50 \\
cyclohexene & 40 & 35 & 30 & 20 & 42 & 30 \\
2,3-dimethyl-2- & 35 & 0 & 0 & 0 & 0 & 35 \\
$\begin{array}{c}\text { butene } \\
\text { trans -2-butene }\end{array}$ & 30 & 0 & & & & 40 \\
\hline
\end{tabular}

From the data displayed in Table 1 it is immediately apparent that the yield of cyclopropanation reaction varies widely with the alkene and the nitrodiazo precursor. The reaction works best with electron rich, unhindered alkenes. While 9a and $9 \mathrm{~g}$ cyclopropanate all of the alkenes chosen for this study, 9b-e, which bear sterically demanding substituents, 
generally do not cyclopropanate trans- and tetra-substituted alkenes. Moreover, there is a decrease in yield in proceeding down the columns from isobutene to cyclohexene.

For the most part, when mixtures of isomers are formed a chromatographic separation is not possible. The exceptions are phenyl substituted cyclopropanes and nitrocyclopropanes derives from nitrodiazomethane. Fortunately, in most other cases the diastereoselectivity is good. There are three different sites available for chemical modification in the molecules 11: the nitro group, the substituent $\mathrm{R}$ and the cyclopropane ring. In this context (Scheme 6), $\mathbf{1 1}$ can be converted into the amino derivatives $\mathbf{1 2}$ by catalytic hydrogenation at medium pressure, or into the derivatives $\mathbf{1 3}$ by chemoselective conversion of the functionality $\mathrm{R}$ into an other functional group, or into the open compound $\mathbf{1 4}$ (when $\mathrm{R}=\mathrm{CO}_{2} \mathrm{Et}$ ) by treatment with nucleophile $\mathrm{AB}$, and into the isoxazoline $\mathrm{N}$-oxides $\mathbf{1 5}$ by heating or by treatment with an acid.

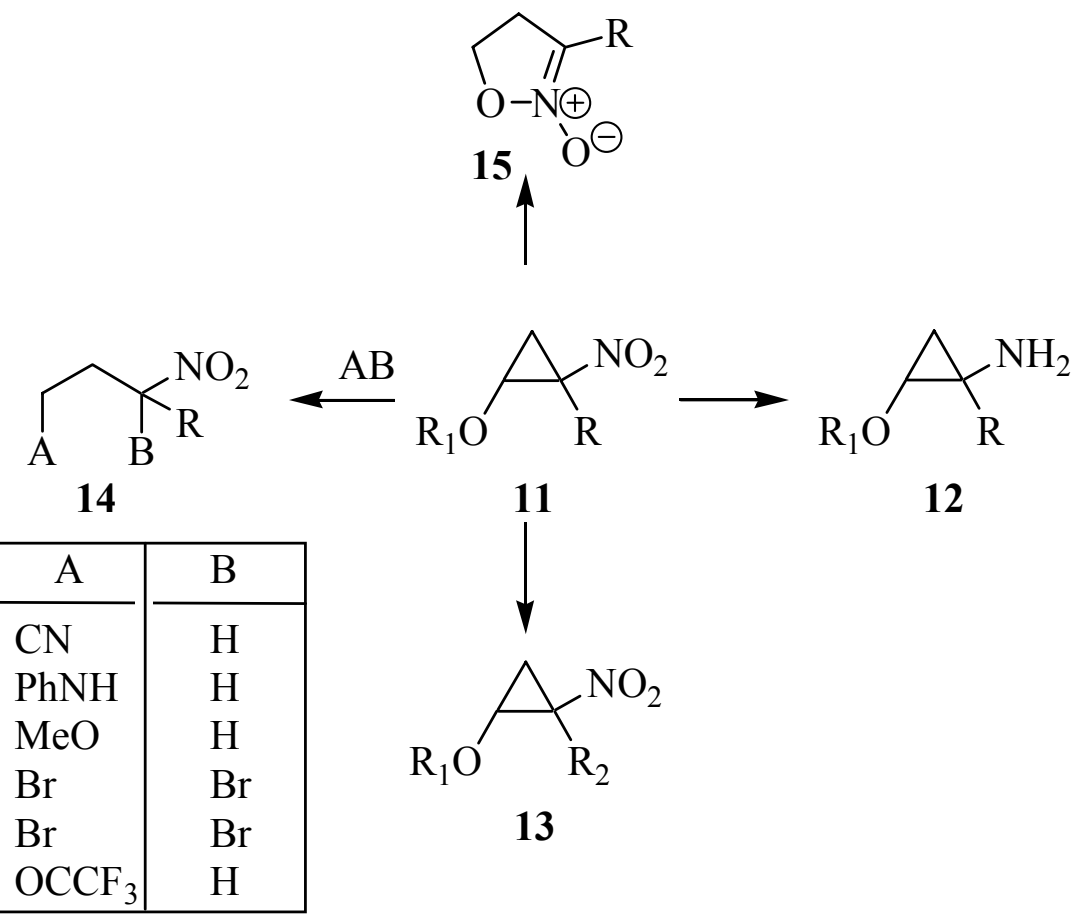

\section{Scheme 6}

Nitroacetic acid is stable in acidic aqueous solution, and its dianion is stable in basic solution, yet in neutral aqueous solution the monoanion decarboxylates within seconds. Other acyclic 1-nitrocarboxylic acids behave similarly. ${ }^{21}$ Thus, of particular interest is the decarboxylation of $\mathbf{1 1}(\mathrm{R}=\mathrm{COOEt})$ since 1-nitrocyclopropanecarboxylic acid and its sodium salt is strongly resistant to decarboxylation because the additional ring strain associated with the introduction of an $\mathrm{sp}^{2}$ atom into a three-membered ring (Scheme 7). 


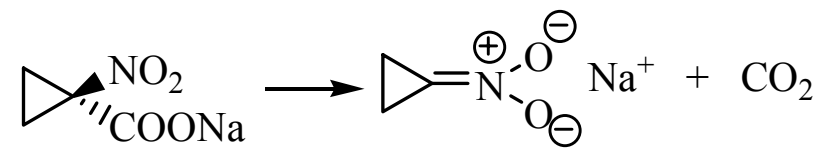

Scheme 7

The esters of $\mathbf{1 1}$ can be converted to the sodium carboxylate $\mathbf{1 6}$ with ethanolic $\mathrm{NaOH}$ solution at room temperature (Scheme 8). ${ }^{22}$

Decarboxylation of these salts in wet DMSO solution occurs at $80{ }^{\circ} \mathrm{C}$ to produce nitrocyclopropanes 17 in almost quantitative yields (Table 3). The reaction presumably proceeds via the 1-nitrocyclopropyl anion showed in Scheme 7.

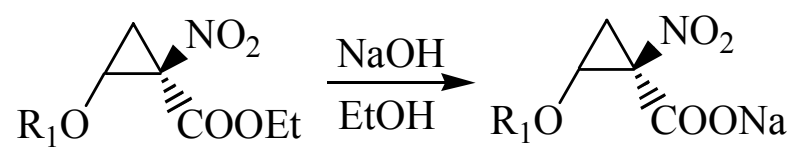

11

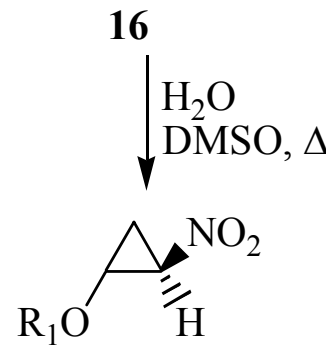

17

\section{Scheme 8}

Table 3. Decarboxylation of $\mathbf{1 1}$

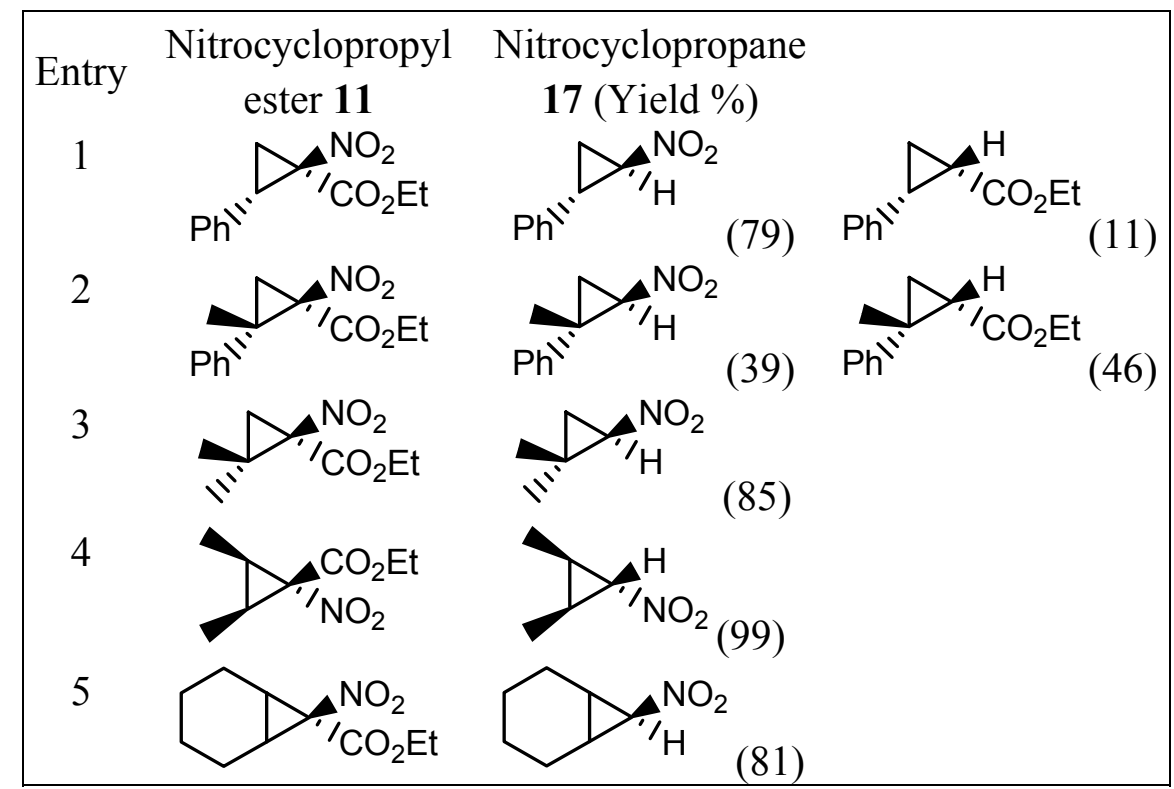




\subsection{Synthesis of cyclopropane $\alpha$-amino acids and amines}

Considerable interest has been drawn to cyclopropane $\alpha$-amino acids (ACCs) in recent years on account of their diverse biological activities as low molecular weight enzyme inhibitors or as nonproteogenic components in peptides. Moreover, they occur naturally ${ }^{23}$ as the immediate biosynthetic precursor of the plant hormone, ${ }^{24}$ and also display properties of pharmaceutical interest when incorporated into peptides.

A practical synthesis for the preparation of a diverse series of cyclopropane $\alpha$-amino acids has been reported through treatment of $\alpha$-nitro esters and iodobenzene diacetate (method B) or $\alpha$ nitro- $\alpha$-diazoesters with a $\mathrm{Rh}(\mathrm{II})$ catalyst (method A) and an olefin (Scheme 9). ${ }^{25}$<smiles>[R]OC(=O)C[N+](=O)[O-]</smiles>

18

$$
\begin{array}{l|l}
{\left[\mathrm{Rh}(\mathrm{OPiv})_{2}\right]_{2}} \\
(0.5 \mathrm{~mol} \%)
\end{array} \mid \begin{aligned}
& \mathrm{PhI}(\mathrm{OAc})_{2}(1.1 \text { equiv }) \\
& \text { Alkene }(3-5 \text { equiv }), 2 \mathrm{~h} \\
& \text { Metod B }
\end{aligned}
$$

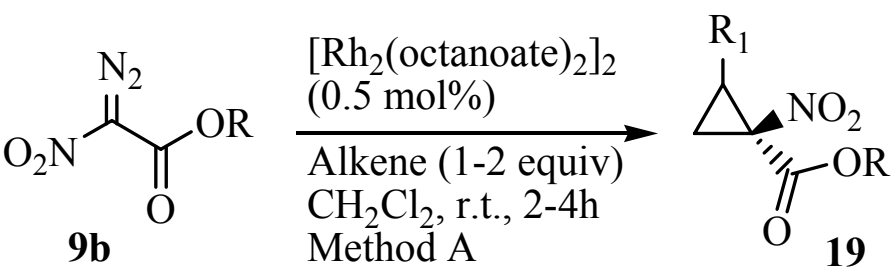

9b Method A

19

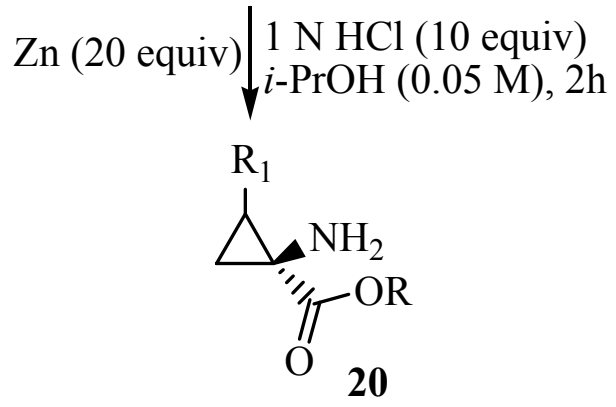

\section{Scheme 9}

The method B represents an alternative way to the method A in order to avoid the use of the potentially dangerous $\alpha$-nitro- $\alpha$-diazocarbonyl substrates. In this method, iodobenzene diacetate was used to directly effect a cyclopropanation reaction between $\alpha$-nitrocarbonyls $\mathbf{1 8}$ and olefins in the presence of a catalyst (Table 4). This cyclopropanation presumably proceeds via an iodonium ylide intermediate formed in situ. However, cyclopropanation using method A and $\mathrm{B}$ allows access to a diverse series of nitrocyclopropanes carboxylates 19. In most cases, similar chemical yields and diastereoselectivities can be obtained for a variety of substrates 
either method A or method B (Table 4). Electron-rich and-deficient styrene derivatives are well tolerated by both methods (entry 1-4).

Table 4. Nitrocyclopropanes 19 and amino acids 20 prepared

\begin{tabular}{|c|c|c|c|c|c|}
\hline Entry & Cyclopropane 19 & Method & $\begin{array}{c}E: Z \\
\text { Ratio }\end{array}$ & $\begin{array}{c}\text { Yield }(\%) \\
\text { of } 19 \\
\end{array}$ & $\begin{array}{c}\text { Yield }(\%) \\
\text { of } \mathbf{2 0} \\
\end{array}$ \\
\hline \multirow[t]{3}{*}{1} & $\underline{P h}$ & A & & 90 & \multirow{3}{*}{77} \\
\hline & $\triangle \mathrm{NO}_{2}$ & & $93: 7$ & & \\
\hline & $\mathrm{CO}_{2} \mathrm{Et}$ & B & & 84 & \\
\hline \multirow[t]{3}{*}{2} & & $\mathrm{~A}$ & & 86 & \multirow{3}{*}{76} \\
\hline & & & $95: 5$ & & \\
\hline & & $\mathrm{B}$ & & 87 & \\
\hline & $\mathrm{CO}_{2} \mathrm{Me}$ & & & & \multirow[b]{2}{*}{74} \\
\hline 3 & $m-$ TBDPSOC $_{6} \underline{\mathrm{H}}_{4}$ & A & $92: 8$ & 92 & \\
\hline \multirow[t]{3}{*}{4} & $p-\mathrm{ClC}_{6} \underline{\underline{H}}_{4}$ & A & & 87 & \multirow{3}{*}{76} \\
\hline & $\mathrm{NO}_{2}$ & & $91: 9$ & & \\
\hline & & B & & 80 & \\
\hline 5 & & A & $53: 47$ & 70 & 93 \\
\hline \multirow[t]{3}{*}{6} & $\mathrm{NO}_{2}$ & $\mathrm{~A}$ & & 79 & \multirow{4}{*}{79} \\
\hline & & & $97: 3$ & & \\
\hline & & B & & 83 & \\
\hline \multirow[t]{3}{*}{7} & $\mathrm{NO}_{2}$ & $\mathrm{~A}$ & & 84 & \\
\hline & & & $97: 3$ & & \multirow[t]{2}{*}{86} \\
\hline & & $\mathrm{B}$ & & 72 & \\
\hline
\end{tabular}

The nitrocyclopropanes 19 can be easily converted into the amino acids 20 by their treatment with 20 equiv of zinc (dust) and 10 equiv of aqueous $1 \mathrm{~N} \mathrm{HCl}$ in 2-propanol $(0.05 \mathrm{M})$. However, the best results (Table 4) were obtained when zinc dust was added in small portions over $15 \mathrm{~min}$ (exothermic reaction) to the acidic alcohol solution containing the cyclopropane. The amino esters $\mathbf{2 0}$ can be then converted into the corresponding amino acids by saponification of the ester according to previously reported methods. ${ }^{26}$ 
There has been much interest in the preparation of cyclopropyl amines as they are found in a number of biologically active products. In this context, by a slight modification of the procedure reported by O'Bannon and Dailey, ${ }^{22}$ some nitrocyclopropane carboxylates $\left(\mathrm{R}^{1}=\mathrm{Aryl}\right)$ were treated (Scheme 10) with $\mathrm{NaOH}$ in a mixture of $\mathrm{DMSO} / \mathrm{H}_{2} \mathrm{O}$ and heated to $80{ }^{\circ} \mathrm{C}$ for $2 \mathrm{~h}$, resulting in the saponification and then decarboxylation of the nitrocyclopropane carboxylate to afford 21.

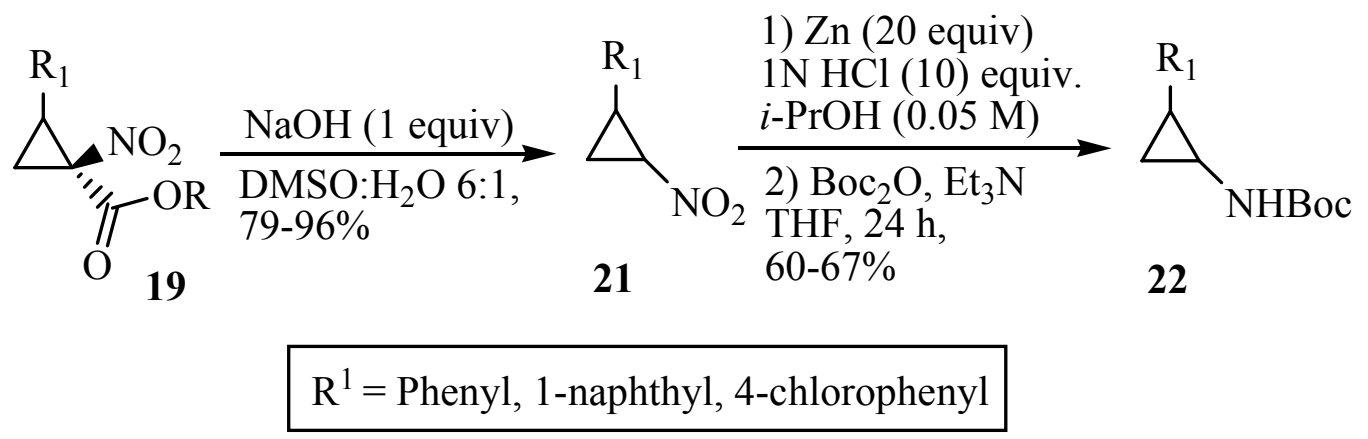

\section{Scheme 10}

These cyclopropanes were found to efficiently yield the corresponding cyclopropyl amines under the standard conditions (trans:cis $=81-83 / 17-19$ ). The Rh- or Cu-catalyzed cyclopropanation using either diazo or phenyliodonium ylide derivatives of $\alpha$-nitro esters, with alkenes affords substituted 1-nitrocyclopropanes in good yields and diastereocontrol but with poor enantiocontrol (Scheme 9). ${ }^{25}$ Later, the same authors optimized the method by the use of $\mathrm{Cu}(\mathrm{I})$-bis(oxazoline) complex in order to obtain an important improvement in asymmetric preparation of cyclopropane $\alpha$-amino acids. ${ }^{27}$ After several trials, the best results were those reported in Scheme 11.

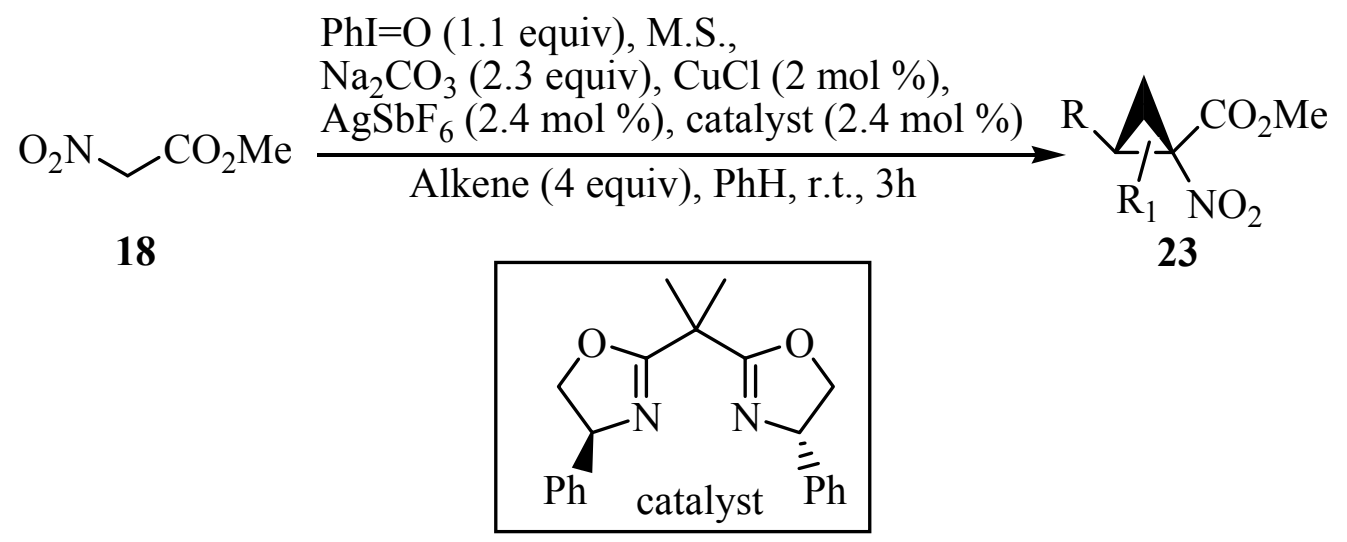

\section{Scheme 11}


The catalyst, isopropylidene bis(4-phenyl-2-oxazoline), is commercially available and needs the presence of molecular sieves (M.S.) to scavenge water. The use of $\mathrm{Na}_{2} \mathrm{CO}_{3}$ was found to be optimal for the full consumption of the starting material. The obtained results are listed in Table 5.

Table 5. Asymmetric cyclopropanation with $\mathrm{Cu}(\mathrm{I})$

\begin{tabular}{|c|c|c|c|c|}
\hline Entry & Alkene & $\begin{array}{c}\text { Yield }(\%) \\
\text { of } \mathbf{2 3} \\
\end{array}$ & $\mathrm{dr}$ & ee \\
\hline 1 & $\mathrm{PhCH}=\mathrm{CH}_{2}$ & 82 & $94: 6$ & 91 \\
\hline 2 & $p-\mathrm{ClC}_{6} \mathrm{H}_{4} \mathrm{CH}=\mathrm{CH}_{2}$ & 45 & $92: 8$ & 91 \\
\hline 3 & $p-\mathrm{MeOC}_{6} \mathrm{H}_{4} \mathrm{CH}=\mathrm{CH}_{2}$ & 71 & $93: 7$ & 68 \\
\hline 4 & $p-\mathrm{MeC}_{6} \mathrm{H}_{4} \mathrm{CH}=\mathrm{CH}_{2}$ & 76 & $93: 7$ & 92 \\
\hline 5 & 1-NaphthCH= $\mathrm{CH}_{2}$ & 53 & $93: 7$ & 91 \\
\hline 6 & 2-NaphthCH $=\mathrm{CH}_{2}$ & 74 & $91: 9$ & 91 \\
\hline 7 & $2,4,6-\mathrm{MeC}_{6} \mathrm{H}_{2} \mathrm{CH}=\mathrm{CH}_{2}$ & 54 & $95: 5$ & 93 \\
\hline 8 & $p-\mathrm{Bu}^{t} \mathrm{OC}_{6} \mathrm{H}_{4} \mathrm{CH}=\mathrm{CH}_{2}$ & 80 & $93: 7$ & 90 \\
\hline 9 & Indene & 72 & $95: 5$ & 98 \\
\hline 10 & 1,3-butadiene & 84 & $82: 18$ & 90 \\
\hline
\end{tabular}

The nitrocyclopropanes $\mathbf{2 3}$ can be converted in high yields into aminoesters by a simple Zn-mediated reduction, as in Scheme 9 (19 to 20), without any loss of the high enantioselection. Thus, since the $\alpha$-amino esters are the immediate precursors of $\alpha$-amino acids by their saponification, the reported asymmetric cyclopropanation represents a new three-step way of enantiomerically enriched cyclopropane $\alpha$-amino acids.

\section{Intramolecular cyclopropanation of $\gamma$-nitro alcohols}

$\gamma$-Nitro alcohols are a class of functionalized nitro alkanes in which the hydroxyl can act as leaving group in different way, allowing an intramolecular nucleophilic substitution by the action of a carbanion generated, as nitronate form, from the atom bearing the nitro group.

\subsection{Intramolecular Mitsunobu displacement}

Treatment of a wide variety of $\gamma$-nitroalkanols with a preformed complex of diethyl azodicarboxylate (DEAD) and triphenylphosphine affords $\alpha$-nitrocyclopropanes in good to excellent yields (Table 6). ${ }^{28}$ 
The reaction proceeds rapidly at ambient temperature under essential neutral conditions in benzene or THF. This Mitsunobu ${ }^{29}$ displacement procedure in which a nitronate anion acts as a carbon nucleophile resulting in a new carbon-carbon bond. Competitive alkylation of the oxygen in the ambident nitronate anion is not observed.

Table 6. Mitsunobu cyclopropanation of $\gamma$-nitro alcohols

\begin{tabular}{|c|c|c|c|c|}
\hline Entry & Nitro alcohol & Product & trans/cis & $\begin{array}{c}\text { Yield } \\
(\%)\end{array}$ \\
\hline 1 & & & 10:1 & 82 \\
\hline 2 & & & $10: 1$ & 87 \\
\hline 3 & & & trans & 92 \\
\hline 4 & & & trans & 76 \\
\hline 5 & & & trans & 75 \\
\hline 6 & & & $7: 1$ & 92 \\
\hline 7 & $\mathrm{OH}$ & & $\begin{array}{c}\text { trans } \\
\text { only }\end{array}$ & 64 \\
\hline 8 & $\mathrm{NO}_{2}$ & & $\begin{array}{l}\text { trans } \\
\text { only }\end{array}$ & 94 \\
\hline 9 & hro & & $\begin{array}{c}\text { not } \\
\text { applicable }\end{array}$ & 98 \\
\hline 10 & & & - & 0 \\
\hline
\end{tabular}


As reported in Table 6, acyclic primary (entry 1) and secondary (entry 2) nitro alcohol react smoothly as do related carbocycles (entry 3 ) including a $5 \alpha$-cholestane derivatives (entry 4). Since the products are configurationally stable under the reaction conditions, the predominant trans-disposition of the nitro group presumably reflects kinetic rather than thermodynamic factors. Even alcohol prone to dehydration (entries 5 and 6) give cyclopropanes without complication. No allylic transposition or $\mathrm{S}_{\mathrm{N}} 2$ ' products are detected in the closure leading to the conjugate cyclopropane in entry 7. Moreover, the cyclizations of threo- and erythro-nitro alcohols (entry 8 and 9, respectively) are completely stereospecific ( $>95 \%$ ). Finally, hindered alcohols such as the one in entry 10 are unreactive and starting material is returned.

\subsection{Synthesis of 3-(trans-2'-nitrocyclopropyl)alanine}

The peptide-lactone hormaomycin 1 (Fig. 1) produced by Streptomyces griseoflavus shows a selective antibiotic effect against some gram-positive bacteria. This intercellular signal substance has an influence on the formation of air mycel as well as the production of secondary metabolites in streptomyces. The structure includes two molecules of 3-(trans-2'-nitrocyclopropyl)-alanine 30 in with a trans oriented nitro group and both possible configurations at C-2.

de Maijere and coll. ${ }^{30}$ reported a synthetic strategy toward $\mathbf{3 0}$ in which the cyclopropanation step is the key step. The sequence (Scheme 12) was realized with the readily available starting material $(R)$ - and (S)-2,3-O-isopropyllideneglyceraldehyde 24, which can be transformed to the protected 4-nitrobutane-1,2-diol 25 by one-pot reductive nitromethylation.

The acetal in $\mathbf{2 5}$ is cleaved with $\mathrm{TsOH}$ and the primary hydroxy group in diol 26 selectively protected with triphenylmethyl chloride in pyridine. The secondary hydroxyl group in the ether $\mathbf{2 7}$ is transformed into a leaving group with methanesulfonyl chloride/triethylamine, and the obtained $\mathbf{2 8}$ is treated under basic conditions with sodium carbonate in toluene. The $\gamma-$ elimination occurs with complete inversion of configuration at C-2 to give only the transconfigured nitrocyclopropane $\mathbf{2 9}$. The latter is easily converted into the target amino acid $\mathbf{3 0}$ in four more steps. 


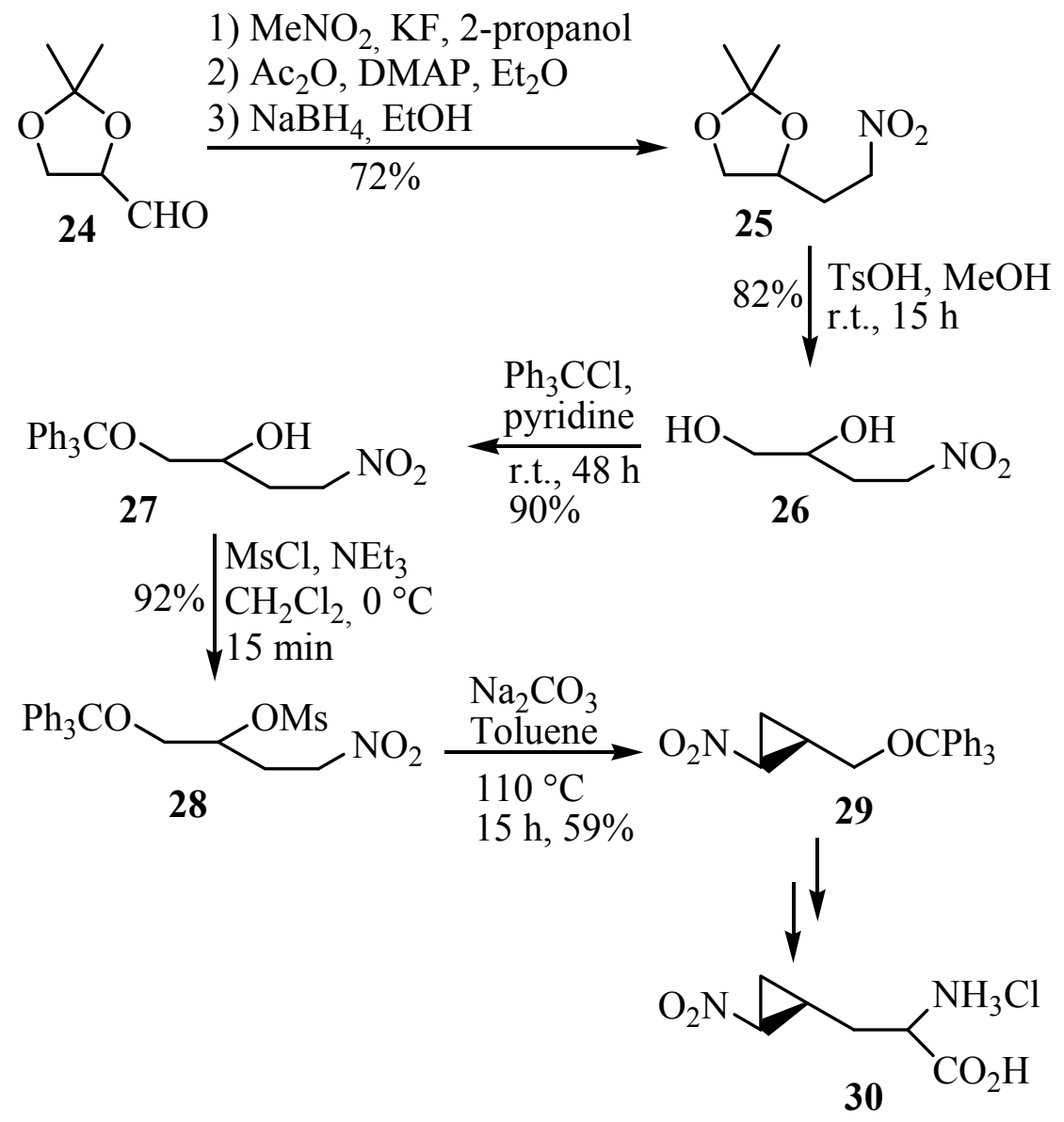

\section{Scheme 12}

\section{Cyclopropanation of tert-butyl 2,3-dibromopropanoate}

tert-Butyl 2,3-dibromopropanoate has been recognized as possible key building block for the one-pot generation of functionalized nitrocyclopropanes prone to be converted into $\beta$ aminoacids or other important targets with biological activity. In fact, as reported in Scheme 13, tert-butyl 2,3-dibromopropanoate $\mathbf{3 1}$ by treatment with nitromethane in DMSO and in the presence of potassium carbonate as base, yields tert-butyl trans-2-nitrocyclopentane 32 in satisfactory overall yields $(59 \%){ }^{31}$ 


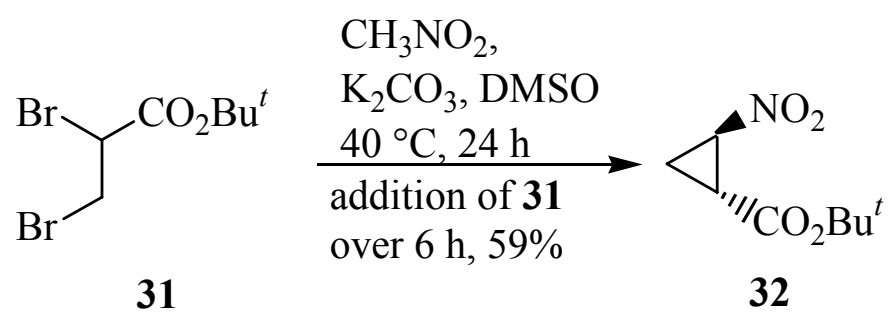

\section{Scheme 13}

The easy access to $\mathbf{3 2}$ has stimulated the same authors to report the synthesis (Scheme 14) of 3-(trans-2-aminocyclopropyl)alanine 36, a key constituent of belactosin A which shows antitumor activity.

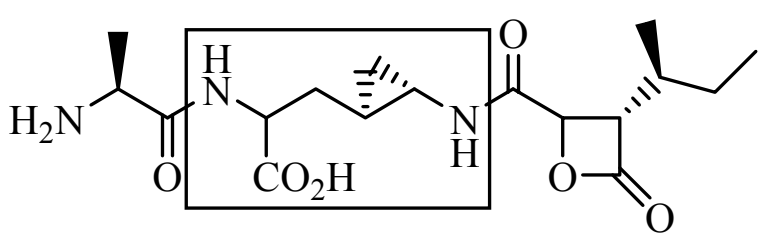

Belactosin A

Figure 2

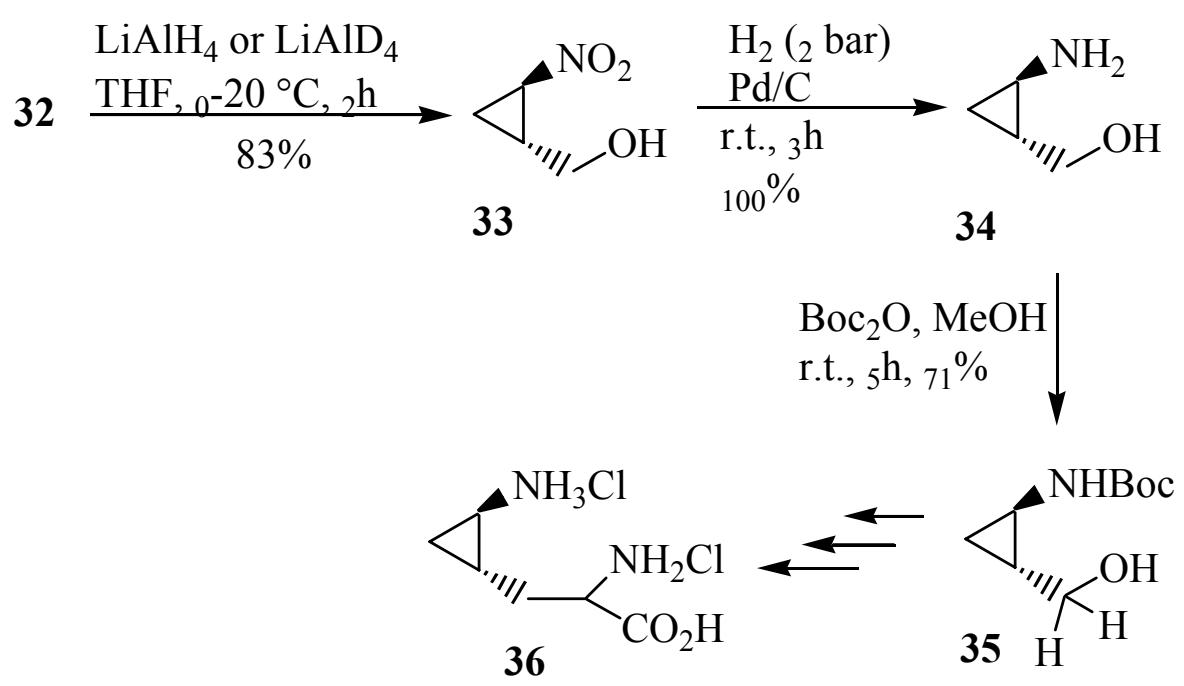

\section{Scheme 14}

Later, the same authors reported an improved approach in which $\mathbf{3 2}$ is the key building block for the preparation of all four diastereomers of 3-(trans-2-nitrocyclopropyl)alanine, precursors of $36 .^{32}$ 


\section{Cyclopropanation of conjugate nitroalkenes}

Nitroalkenes have found wide application in organic synthesis. ${ }^{2 \mathrm{~d}}$ Their character as electron deficient alkenes allows easy 1,4-addition reactions or cycloaddition to the $\mathrm{C}-\mathrm{C}$ double bond. Recently the stereoselective 1,3-dipolar additions to diazomethane to nitroalkenes derived from gliceraldehyde was reported. ${ }^{33}$ Elimination of nitrogen from the resulting pyrazolines gave access to chiral nitrocyclopropanes. Few years ago, Pätzel et al. ${ }^{34}$ discovered that nitroalkenes gave cyclopropanation with sulphur ylides or dibromocarbene (Scheme 15).

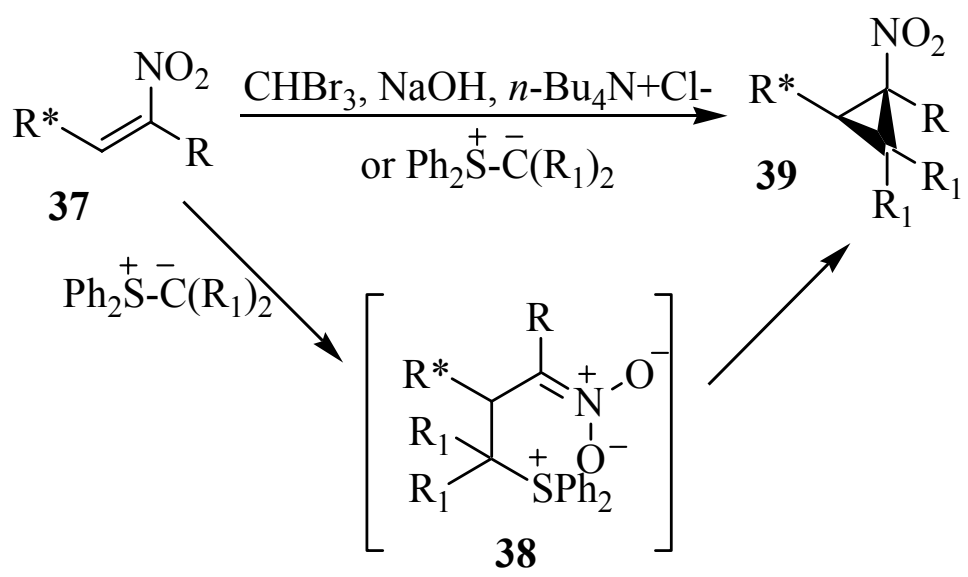

\section{Scheme 15}

Polymerisation of the nitroalkene and formation of other by products were occasionally observed as side reaction.

As reported in Table 7, the nitrocyclopropanes 39 were obtained in moderate to satisfactory yields and in a diastereoselective manner.

These nitrocyclopropanes have been then used to synthesize optically active $\beta$-amino acids by reduction of the nitro group and oxidative cleavage of the dioxolane substituent. 
Table 7. Cyclopropanation of nitroalkenes. Selected examples

\begin{tabular}{|c|c|c|c|c|c|}
\hline Entry & $\mathrm{R}^{*}$ & $\mathrm{R}$ & $\mathrm{R}_{1}$ & $\begin{array}{c}\text { Yield }(\%) \\
\text { of } \mathbf{3 9}\end{array}$ & $\begin{array}{c}\text { Diastereomeric } \\
\text { ratio of } \mathbf{3 9}\end{array}$ \\
\hline 1 & & $\mathrm{H}$ & $\mathrm{Me}$ & 60 & $7: 3$ \\
\hline 2 & & $\mathrm{Me}$ & $\mathrm{Me}$ & 90 & $9.7: 0.3$ \\
\hline 3 & & $\mathrm{Me}$ & $\mathrm{H}$ & 25 & $6: 4$ \\
\hline 4 & & $\mathrm{Me}$ & $\mathrm{Me}$ & 74 & $9.5: 0.5$ \\
\hline 5 & & $\mathrm{Me}$ & $\mathrm{Me}$ & 37 & $9.7: 0.3$ \\
\hline 6 & & $\mathrm{Me}$ & $\mathrm{Me}$ & 54 & $5: 5$ \\
\hline
\end{tabular}

\section{Cyclopropanation by Michael addition of bromonitromethane to electron-poor alkenes}

Recent report from our laboratory has disclosed that nitroalkanes $\mathbf{4 0}$ react with electrophilic alkenes 41, bearing two electron-withdrawing groups in the $\alpha$ - and $\beta$-positions, by a tandem Michael addition-elimination processes, giving the unsaturated derivatives $\mathbf{4 2}$ (Scheme 16). ${ }^{35}$

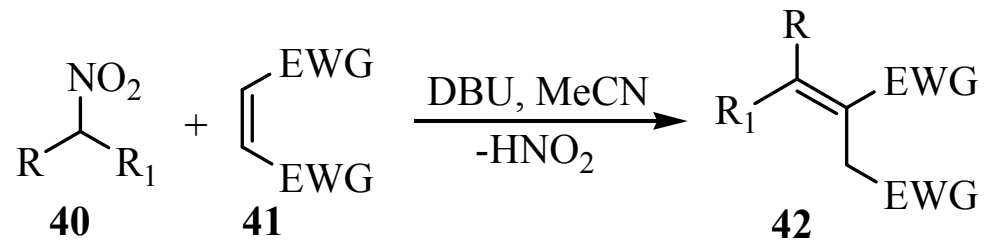

Scheme 16 
Therefore, based on both (i) our previous experience and (ii) the preliminary result obtained by Braish et al. $^{36}$ in the cyclopropanation of $N$-benzylmaleimide 43a by bromonitromethane 44 (Scheme 17), we tested the possibility to develop a general and efficient procedure for the preparation of nitrocyclopropanes by the reaction of several linear electrophilic alkenes 46 with 44, in the presence of potassium carbonate as base (Scheme 18). ${ }^{37}$

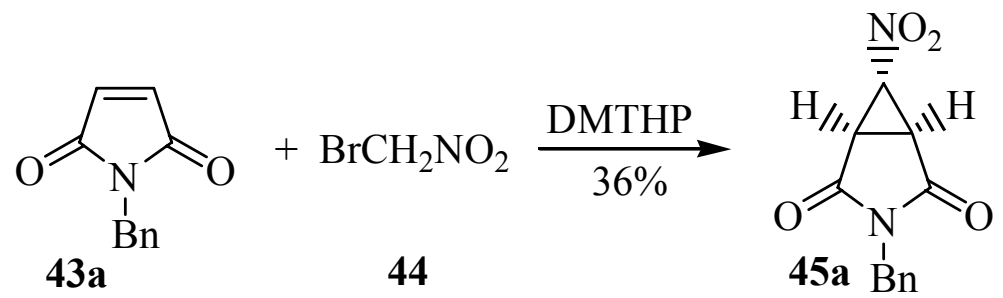

$43 a$

44<smiles>CC1=NCCCN1C</smiles>

Dimethyl-1,3,4,5-tetrahydropyrimidine (DMTHPM)

\section{Scheme 17}

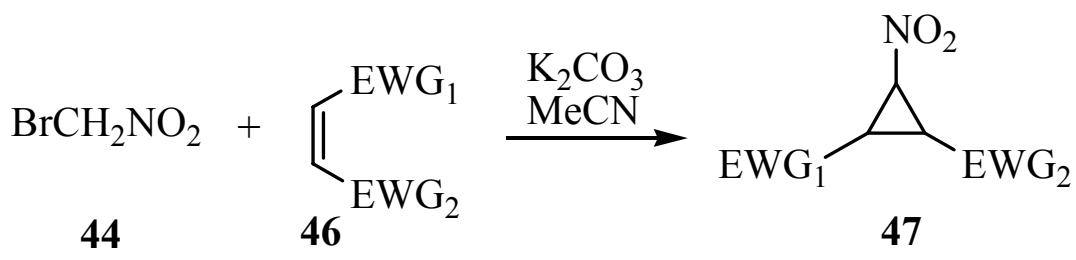

\section{Scheme 18}

The success of the method depends from the correct addition of $\mathbf{4 4}$ to the basic solution of the alkene 46. In fact, it is important to add nitromethane in several fractions in order to avoid its decomposition that has been observed under basic conditions.

The yields of cyclopronatanion to 47 proceeds in good to excellent yields $(75-96 \%$, Table 8 ) with a variety of substrates, while the diastereoselectivity was modest. 
Table 8. Cyclopropanation of bromonitromethane

\begin{tabular}{|ccccc|}
\hline Entry & EWG $_{1}$ & EWG $_{2}$ & $\begin{array}{c}\text { Yield (\%) } \\
\text { of 47 }\end{array}$ & $\begin{array}{c}\text { Diastereomeric } \\
\text { ratio of 47 }\end{array}$ \\
\hline 1 & $\mathrm{MeCO}$ & $\mathrm{MeCO}$ & 94 & $23: 77$ \\
2 & $\mathrm{PhCO}$ & $\mathrm{MeCO}$ & 96 & $88: 12$ \\
3 & $p-\mathrm{MeC}_{6} \mathrm{H}_{4} \mathrm{CO}$ & $\mathrm{MeCO}$ & 96 & $84: 16$ \\
4 & $\mathrm{PhCO}_{5}$ & $\mathrm{PhCO}$ & 75 & $15: 85$ \\
5 & $\mathrm{COOMe}$ & $\mathrm{MeCO}$ & 86 & $69: 31$ \\
6 & $\mathrm{COOMe}$ & $\mathrm{COOMe}$ & 88 & $40: 60$ \\
7 & $\mathrm{CN}$ & $\mathrm{CN}$ & 78 & $70: 30$ \\
\hline
\end{tabular}

Further investigation was devoted to the cyclopropanation by bromonitromethane and different $N$-alkylmaleimides $\mathbf{4 3}$, following the same procedure, with the formation of exocyclopropane derivatives 45 (Scheme 19).

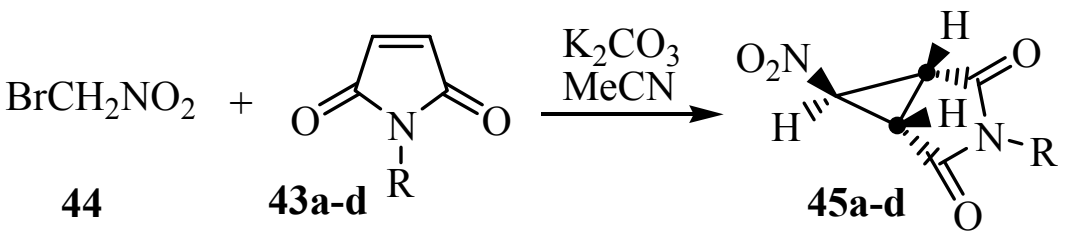

\section{Scheme 19}

Good yields were obtained (Table 9) and it is important to point out that the compound 45a, previously prepared in 36\% yield (Scheme 17), has been achieved in 70\% yield. Moreover, compounds $\mathbf{4 5}$ include several interesting frameworks that could allow selective manipulation to give other important functionalities.

Table 9. Preparation of exo-nitrocyclopropanes 45

\begin{tabular}{|cccc|}
\hline 45 & $\mathrm{R}$ & $\begin{array}{c}\text { Yield (\%) } \\
\text { of } \mathbf{4 5}\end{array}$ & $\begin{array}{c}\text { Reaction time } \\
(\mathrm{h})\end{array}$ \\
\hline a & $\mathrm{Bn}$ & 70 & 48 \\
$\mathbf{b}$ & $\mathrm{Et}$ & 70 & 24 \\
c & $t-\mathrm{Bu}$ & 82 & 48 \\
d & $\mathrm{Me}$ & 65 & 24 \\
\hline
\end{tabular}

The cyclopropanation with bromonitromethane has been the key step for the synthesis of trovafloxacin 48 (Scheme 20), a novel broad spectrum antibacterial, by Norris et al. ${ }^{38}$ 


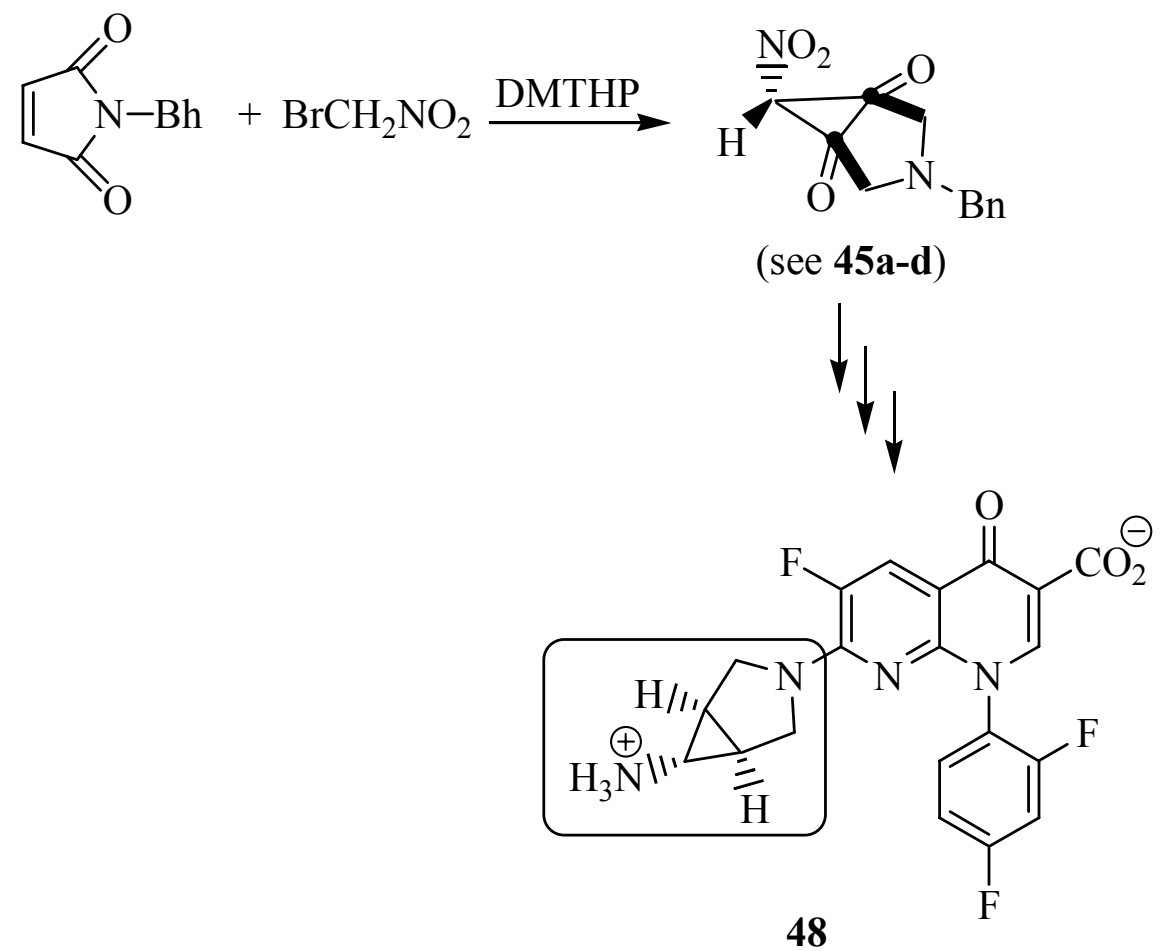

Scheme 20

\section{Conclusions}

Many synthetic approaches directed to the preparation of nitrocyclopropane derivatives demonstrate the great importance of this molecular structure. Although other synthetic procedures have been reported in the literature, ${ }^{39}$ our focus is directed to give a panorama of the main reported ones. We believe that this micro-report could be of interest since nitrocyclopropane structures possess, simultaneously, at least two important properties: (i) high versatility due to the presence of the nitro group, and (ii) a strained-ring that can be inserted in many important targets.

\section{Acknowledgements}

Financial support has been granted by MIUR-Italy and the University of Camerino. 


\section{References}

1. Ballini, R., In Studies in Natural Products Chemistry; Atta-ur-Rahman, Ed.; Elsevier: Amsterdam, 1997; Vol.19, p 117.

2. (a) Seebach, D.; Colvin, E. W.; Lehr, F.; Weller, T., Chimia 1979, 33, 1. (b) Rosini, G.; Ballini, R., Synthesis 1988, 833. (c) Rosini, G.; Ballini, R.; Petrini, M.; Marotta, E.; Righi, P., Org. Prep. Proc. Int. 1990, 22, 707. (d) Ono, N., The Nitro Group in Organic Synthesis; Wiley-VCH: New York, 2001. (e) Ballini, R.; Petrini, M., Tetrahedron 2004, 60, 1017.

3. (a) The Chemistry of Amino, Nitroso, Nitro and Related Groups; Patai, S. Ed.; Wiley: Chichester, 1996. (b) Adams, J. P., J. Chem. Soc., Perkin Trans 1 2002, 2586.

4. (a) Rosini, G., In Comprehensive Organic Synthesis; Trost, B. M. Ed.; Pergamon: Oxford, 1991, 2, 321. (b) Luzzio, F. A., Tetrahedron 2001, 57, 915.

5. Ballini, R.; Bosica, G.; Fiorini, D.; Palmieri, A.; Petrini, M., Chem. Rev. 2005, 105, 933.

6. Ballini, R.; Bosica, G.; Fiorini, D.; Palmieri, A., Tetrahedron 2005, 61, 8971.

7. (a) Kai, Y.; Knochel, P.; Kwiatkowski, S.; Dunitz, J. D.; Oth, J. F. M.; Seebach, D.; Kalinowski, H. O., Helv. Chim. Acta 1982, 65, 137. (b) Ballini, R., Synlett 1999, 1009.

8. (a) Agrawal, J. P., Prog. Energy Combust. Sci. 1998, 24, 1. (b) Olah, G. A.; Malhotra, R.; Narang, S. C.; In Nitration Methods and Mechanism, Feuer, H. Ed.; VCH: New York, 1989.

9. Alster, J.; Iyer, S.; Sandus, O., Chemistry and Physics of Energetic Materials, Bulusu, S. N., Ed.; Kluwer Academic Publishers: Dordrecht, The Netherland, 1990, 641.

10. Patagoria, P. F.; Lee, G. S.; Mitchell, A. R.; Schmidt, R. D., Termochimica Acta 2002, 384, 187.

11. (a) Marchand, A. P.; Rajagopal, D.; Bott, S. G.; Archibald, T. G., J. Org. Chem. 1995, 60, 4943. (b) Axenrod, T.; Watnick, C.; Yazdekhasti, H.; Dave, P. R., J. Org. Chem. 1995, 60, 1959.

12. Zlatopolskiy, B. D.; Radzom, M.; Zeeck, A.; de Meijere, A., Eur. J. Org. Chem. 2006, 1525.

13. Kocór, M., Kroszczński, W., Synthesis 1976, 813.

14. Kohler, E. P.; Engelbrecht, H. F., J. Am. Chem. Soc. 1919, 41, 1379.

15. Sopova, A. S.; Perekalin, V. V.; Yurchenko, O. I.; Arnautova, G. M., Zh. Org. Khim. 1969, 5, 858; C. A. 1969, 71, 38394.

16. Arai, S.; Nakayama, K.; Ishida, T.; Shioiri, T., Tetrahedron Lett. 1999, 40, 4215.

17. Arai, S.; Nakayama, K.; Hatano, K.; Shioiri, T., J. Org. Chem. 1998, 54, 9572.

18. Ono, N.; Kaji, A., Synthesis 1986, 693.

19. (a) Mash, E. A.; Nelson, K. A., Tetrahedron 1987, 43, 679. (b) Piqué, C.; Fahndrich, B. ; Pfaltz, A., Synlett 1995, 491.

20. O’Bannon, P. E.; Dailey, W. P., Tetrahedron 1990, 46, 7341.

21. (a) Finkbeiner, H. L.; Stiles, M., J. Am. Chem. Soc. 1963, 85, 616. (b) Pedersen, K. S., Acta Chem. Scand. 1947, 1, 437.

22. O’Bannon, P. E.; Dailey, W. P., J. Org. Chem. 1990, 55, 353. 
23. Burroughs, L. F., Nature 1957, 179, 360.

24. Pirrung, M. C., Acc. Chem. Res. 1999, 32, 711.

25. Wurz, R. P.; Charette, A. B., J. Org. Chem. 2004, 69, 1262.

26. (a) Aggarwal, V. K.; Alonso, E.; Fang, G.; Ferrara, M.; Hynd, G.; Porcelloni, M., Angew. Chem., Int. Ed. 2001, 40, 1433. (b) Yashin, N. V.; Averina, E. B.; Gerdov, S. M.; Kuznetsova, T. S.; Zefirov, N. S., Tetrahedron Lett. 2003, 44, 8241.

27. Moreau, B.; Charette, A. B., J. Am. Chem. Soc. 2005, 127, 18014.

28. Yu, J.; Falck, J. R.; Mioskowski, C., J. Org. Chem. 1992, 57, 3757.

29. Mitsunobu, O., Synthesis 1981, 1.

30. Zindel, J.; Zeeck, A.; König, W. A.; de Meijere, A., Tetrahedron Lett. 1993, 34, 1917.

31. Brandl, M.; Kozhushkov, S. I.; Loscha, K.; Kokoreva, O. V.; Yufit, D. S.; Howard, J. A. K., Synlett 2000, 1741.

32. Larionov, O. V.; Savel'eva, T. F.; Kochetkov, K. A.; Ikonnokov, N. S.; Kozhushkov, S. I.; Yufit, D. S.; Howard, J. A. K.; Khrustalev, V. N.; Belokon, Y. N.; de Meijere, A., Eur. J. Org. Chem. 2003, 869.

33. Muray, E.; Alvarez-Larena, A.; Piniella, J. F.; Branchadell, V.; Ortuño, R. M., J. Org. Chem. 2000, 65, 388.

34. (a) Galley, G.; Hübner, J.; Anklam, S.; Jones, P. G.; Pätzel, M., Tetrahedron Lett. 1996, 37, 6307. (b) Hübner, J.; Liebscher, J.; Pätzel, M., Tetrahedron 2002, 58, 10485.

35. For some selected examples see: (a) Ballini, R.; Barboni, L.; Bosica, G.; Petrini, M., Synlett 2000, 391. (b) Ballini, R.; Bosica, G.; Petrelli, L.; Petrini, M., Synthesis 1999, 1236. (c) Ballini, R.; Marcantoni, E., Perella, S., J. Org. Chem. 1999, 64, 2954. (d) Ballini, R.; Bosica, G.; Fiorini, D.; Righi, P., Synthesis 2002, 681.

36. Braish, T. F.; Castaldi, M.; Chan, S.; Fox, D. E.; Keltonic, T.; McGarry, J.; Hawkins, J. M.; Norris, T.; Rose, P. R.; Sieser, J. E.; Sitter, B. J.; Watson Jr., H., Synlett 1996, 1100.

37. Ballini, R.; Fiorini, D.; Palmieri, A., Synlett 2003, 1704.

38. Norris, T.; Braish, T. F.; Butters, M.; De Vries, K. M. ; Hawkins, J. M. ; Masset, S. S. ; Rose, P. R. ; Santafianos, D. ; Sklavounos, C., J. Chem. Soc., Perkin Trans 1 2000, 1615.

39. During the preparation of the manuscript a new, stereoselective synthesis of highly functionalized nitrocyclopropanes has been published: McCooey, S. H.; McCabe, T.; Connon, S. J., J. Org. Chem. 2006, 71, 7494. 